\title{
KREATIVITAS IDA WAYAN OKA GRANOKA DALAM SENI PERTUNJUKAN BALI
}

\author{
Oleh: \\ Gusti Ngurah Yoga Semadi \\ yogasemadi@stpbi.ac.id \\ Fakultas Ilmu Agama, Seni, dan Budaya \\ Universitas Hindu Indonesia
}

Proses Review 3-8 April, Dinyatakan Lolos 14 April

\begin{abstract}
This article aims atinvestigating the creativity of Ida Wayan Oka Granoka in Balinese performing arts in his hometown (Budakeling Village) and with the Maha Bajra Sandhi studio in Banjar Batu Kandik, Denpasar, with high artistic motivation. Therefore, this article is focused on analyzing the motivations, creative processes, and messages of performance art displayed by Granoka. The results shows that the motives underlying the creativity of Ida Wayan Oka Granoka in Balinese Performing Arts include several aspects (a) genetic, (b) potential, (c) facilities and infrastructure, (d) family support, (e) grace, (f) ) family education, educated by teachers, responding to the phenomenon of present education (g) economics, (h) religion, and (i) idealism consists of niskama karma, abstinence, art as a solution to life, national ideology, and rotation of yadnya chakra. Then, Granoka's creative process in the field of Balinese performing arts goes through several stages of the beginning, middle and end of the process. The results that have been achieved include performing arts, regional literary arts, painting, sound and vocal arts. The messages conveyed in his creativity in the field of Balinese performance art are messages of religious truth (satyam), messages of religious purity (siwam), and messages of religious aesthetics (sundaram).
\end{abstract}

Keywords: Balinese art performance, Granoka, Creativity, Religious.

\begin{abstract}
Abstrak
Artikel ini bertujuan membedah kreativitas Ida Wayan Oka Granoka dalam seni pertunjukan Bali di desa kelahirannya (Desa Budakeling) dan bersama sanggar Maha Bajra Sandhi di Banjar Batu Kandik, Denpasar yang tentu saja ditopang oleh motivasi berkesenian yang tinggi. Oleh karena itu, artikel ini difokuskan menganalisis motivasi, proses kreatif dan pesan karya seni pertunjukan yang ditampilkan oleh Granoka. Hasil penelitian menunjukkan bahwa yang motif yang melatarbelakangi kreativitas Ida Wayan Oka Granoka dalam Seni Pertunjukan Bali meliputibeberapa aspek (a) genetik,
\end{abstract}


(b) kompotensi, (c) sarana dan prasarana, (d) dukungan keluarga, (e) anugrah, (f) pendidikan yaitu dari pendidikan keluarga, didikan dang guru, menyikapi penomena pendidikan sekarang $(\mathrm{g})$ ekonomi, (h) agama, dan (i) idialisme terdiri dari niskama karma, pantang menyerah, seni sebagai solusi hidup, idiologi kebangsaan, dan perputaran yadnya cakra.Kemudian, proses kreatif Granoka di bidang seni pertunjukan Bali melalui beberapa tahapan proses awal, pertengahan dan akhir. Hasil yang telah dicapai meliputi karya seni pertunjukan, seni sastra daerah, seni lukis, seni suara atau vokal. Pesan-pesan yang disampaikan dalam kreativitasnya di bidang seni pertunjukan Bali adalah pesan kebenaran religius (satyam), pesan kesucian religius (siwam),dan pesan estetika religius (sundaram).

Kata Kunci: Seni Pertunjukan,kreativitas, Granoka, religius.

\section{PENDAHULUAN}

Kesenian merupakan sesuatu yang selalu hidup dan terus berkembang. Manusia (seniman) sebagai pendukung utama, kreator seni, semakin berkembang dan semakin menunjukkan jati dirinya. Demikian juga halnya dengan seniman Ida Wayan Oka Granoka yang dalam kreativitas seni pertunjukannya memiliki jadi diri yang kuat, yaitu berkreativitas seni untuk pendakian spiritual.

Di Indonesia, seni pertunjukkan sebagai salah satu cabang seni yang selalu hadir dalam kehidupan manusia, ternyata memiliki perkembangan yang sangat kompleks. Sebagai seni hampir hilang dalam waktu, yang hanya bisa dinikmati apabila seni tersebut sedang dipertunjukkan. Hal ini merupakan masalah yang cukup sulit apabila diteliti (Soedarsono, 2011:1). Seni musik akan mampu dan menghidupkan pertunjukan. Di samping itu musik juga diarahkan untuk memperkecil atau menutupi kekurangan pertunjukan yang terjadi (Hermansyah, 2007:56).

Sebagai sebuah hasil olah rasa,cipta, dan karsa, kesenian tidak dapat dilepaskan dari ikatan nilai-nilai luhur budaya, termasuk estetika yang hidup dan berkembang di lingkungan masyarakat tempat asal seniman yang bersangkutan. Kesenian Bali yang merupakan hasil kreativitas seniman yang berbudaya Bali sangat sarat dengan muatan estetis yang dijiwai oleh nilai-nilai budaya yang bersumber dari agama Hindu (Dibia, 2003:93).

Kreativitas merupakan sebuah persoalan yang bersifat sangat pribadi. Di bidang seni, setiap seniman memiliki tatacara yang berbedabeda dalam melahirkan karya seni. Demikian juga halnya dengan Ida Wayan Oka Granoka (selanjutnya Granoka) yang selalu mengaitkan kreativitasnya dengan pendakian spiritualdalam agama Hindu. Kesenian hasil kreativitas Granoka, yang berasal dari Desa Budakeling, Karangasem sarat dengan nilai-nilai religious perpaduan Siwa dan Buddha di Bali.

Pemahaman terhadap kreativitas Granoka dalam seni pertunjukan Bali, dimulai dari mengenal kehidupan Granoka sejak kelahirannya di Budakeling, Karangasem sampai bisa memunculkan sejumlah karya seni yang mampu menggugah hati para seniman untuk lebih mengingatkan arti seni yang sesungguhnya. Kehadiran Granoka sangat fenomenal karena mampu melahirkan sebuah gagasan baru dalam musik, yakni yogamusik; sebuah gagasan mengonstruksi gamelanBali yang dinamakan yoga musik, sesuai dengan konsep-konsep yoga didalamnya, melalui musik atau gamelan orang dapat melakukan yoga.

Perkembangan ajaran Siwa dan Buddha yang ada di Bali dan boleh dikatakan satu-satunya peninggalannya ada di Desa Budakeling. Perkembangan agama Siwa Buddha yang ada di Bali, seperti yang sudah disebutkan di atas, yaitu ajaran Buddhanya lebih dominan dengan mazhab Buddha Mahayana. Di sini terjadi sinkretisme ajaran Siwa dan Buddha yang telah luluh menjadi satu bagaikan kakak beradik.

Dalam kaitannya dengan kreativitas Granoka dalam seni pertunjukan Bali, Granoka melakukan revitalisasi untuk pemurnian kembali terhadap ajaran Buddha yang berkembang saat ini, yang 
menurut Granoka sudah mengalami transformasi dari ajaran aslinya. Dari sudut pandang Granoka ajaran aslinya adalah seperti ajaran Buddha yang ada dan berkembang di daerah Tibet, menganut ajaran cinta kasih dengan tidak makan daging seperti yang dilakukan dirinya bersama keluarganya.

Hal yang perlu mendapat penekanan bahwa konsep Siwa Buddha yang ada di Bali, khususnya di Budakeling memang berbeda dengan Siwa Buddha sebagaimana diketahui umumnya yang ada dan berkembang di Bali. Sebagai contoh di Bali menganut paham Tri Murthi'tiga perwujudan dewa' dengan kahyangan tiga 'tiga pura, yakni pura Puseh, Desa, dan Dalem'. Namun, di Budakeling yang ada hanyalah pura Dalem seperti yang sudah dijelaskan sebelumnya. Tuhan yang dipuja yang satu itu mengejewantah menjadi bermacam-macam dan yang beraneka tersebut menjadi satu kembali 'Bhineka Tunggal Ika Tan Hana Dharma Mangrwa' hanya ada satu kebenaran Tat'itu' yang tiada lain adalah Brahman 'Tuhan' terlihat berbeda-beda, tetapi pada intinya tidak ada duanya.

Intinya, proses kreatif Granoka dalam berkreativitas di bidang seni pertunjukan Bali ini masih mengadopsi ajaran-ajaran yang memegang teguh kitab Sutasoma dan Sanghyang Kamahayanikan. Ajaran-ajaran inilah yang diolah oleh Granoka sebagai bentuk kreativitasnya untuk melahirkan seni pertunjukan Bali yakni yoga musik pakarana gambelan.

Cara pandang seseorang menentukan sikap hidup. Granoka (2010:9) memandang ketika agama dan filsafat tidak mampu menengahi persoalan-persoalan pelik dalam hidup, seni adalah solusinya. Seni merupakan bentuk pengungkapan rasa indah, halus, tinggi, luar biasa, dan genius. Seni juga mempunyai peranan penting dalam peradaban manusia, yaitu sebagai seismograf supersensitif untuk melihat, mengetahui, dan mengukur adanya gelagat atau ancaman gempa nilai, yang menghancurkan lingkungan tempat tinggal manusia. Seni pada intinya dapat membantu manusia untuk menjawab pertanyaan dari mana ia berasal, ke mana ia hendak menuju, dan siapa dirinya yang sesungguhnya?
Kreativitas Granoka dipilih sebagai objek dalam penelitian ini atas dasar pokok permasalahan yang mendasar ditinjau dari berbagai aspek, seperti seni, sastra, dan agama. Secara objektif, karya-karya Granoka dapat dikatakan menyangkut keunikan bentuk dan struktur formal karya-karya seni pertunjukan. Artinya, di dalamnya terkandung unsur-unsur rasa dan yoga yang dominan, seperti perasaan jiwa yang mendalam saat pertunjukannya. Di samping itu, penarinya melakukan gerakangerakan dalam yoga āsana 'sikap badan dalam yoga'. Kemudian, secara ekspresif, keberadaan Granoka yang merupakan seorang sosok yang sangat unik dan menarik untuk diteliti karena hasil-hasil karyanya penuh nilai estetik, etika, dan sarat dengan makna hidup dan kehidupan. Lalu, masalah kontemplasi, yaitu menyangkut tentang proses Granoka yang mengimajinasikan sesuatu ke dalam karya seni yang diperlakukannya bukan sebagai persembahan seni semata, melainkan juga sebagai praktik yoga. Dalam hal ini ia tidak saja terus berkarya, atau berkarya untuk karya itu sendiri, tetapi juga berkesenian untuk kontemplasi spiritual. Dengan demikian, proses kreatif Granoka pada hakikatnya adalah proses penemuan jati diri dengan jalan yoga musik. Menurut Granoka, dengan berkesenian yang niskama karma orang juga dapat menemukan jati dirinya. Selain itu, konsep-konsep agama Hindu mazhab Siwa dan Buddha menjadi sumber inspirasi. Hal itu dibahasakan dengan gayanya yang khas. Walaupun demikian, sebagian besar masyarakat yang menyaksikan pertunjukan Granoka belum mampu memahami sepenuhnya konsep-konsep atau ide-idenya yang menggunakan aksara atau rerajahan dalam rangka mewujudkan kesenian. Oleh karena itu, dalam artikel ini dibahas motif, proses kreatif, dan pesan-pesan yang hendak disampaikan oleh Granoka melalui seni pertunjukannya.

\section{METODE PENELITIAN}

Kreativitas menurut Suryana (2013:120), adalah kegiatan yang mendatangkan hasil yang sifatnya (1) baru (new), cirinya inovatif, belum ada sebelumnya, segar menarik, serta aneh dan mengejutkan; (2) berguna (usefull), cirinya lebih 
praktis, lebih mudah, memperlancar, mendorong, mengembangkan, mendidik, memecahkan masalah, mengurangi hambatan, mengatasi kesulitan, dan mendatangkan hasil yang lebih baik atau lebih banyak; (3) dapat dimengerti (understable), cirinya hasil yang sama dapat dimengerti dan dibuat pada waktu lain.Kreativitas Ida Wayan Oka Granoka yang dimaksudkan di sini menyangkut proses kerja kreatif seorang seniman Granoka yang menghasilkan karya-karya dalam bidang seni, khususnya seni pertunjukan. Seni pertunjukan itu menyangkut seni gamelan Bali, yakni yoga musik, seni tari, juga seni sastra daerah Bali, seni vokal, seni lukis, dan karya tulis, seperti buku-buku karya Granoka yang sudah diterbitkan. Selain itu, seni merupakan penunjang terbentuknya pribadi yang lengkap di samping dapat membentuk kehalusan budi dan karya. Seni pertunjukan Bali di sini adalah sebuah proses karya seni yang ditampilkan, dipertontonkan, atau dipertunjukan. Dalam hal ini khususnya seni pertunjukan yang mencerminkan agama dan budaya Hindu Bali sebagaisumber karya estetis.

Pembahasan kreativitas Granoka dalam penelitian ini menggunakan pendekatan life story 'Pengalaman hidup' dengan tiga teori, yaitu teori Kreativitas, teori Rasa, dan teori Yoga. Lokasi penelitian mencakup di dua tempat, yakni di Desa Budakeling, Kecamatan Bebandem, Kabupaten Karangasem dan di Banjar Batu Kandik, Padang Sambian Kaja, Denpasar. Penelitian dimulai di Desa Budakeling tempat lahir Granoka dan latar belakang awal mula kreativitasnya. Dilanjutkan di Banjar Batu Kandik, Denpasar, sebagai lokasi tempat tinggal Granoka dan sekaligus aktivitas sanggar MBS. Adapunsubjek yang diteliti adalah berfokus pada kreativitas Granoka terkait dengan kegiatan yang ditekuninya di sanggar MBS. Analisis data dilakukan dengan pendekatan life story'pengalaman hidup'untuk memperoleh bahan keterangan mengenai apa yang dialami oleh individu tertentu di dalam masyarakatnya khususnya tentang kreativitas Ida Wayan Oka Granoka.

\section{ANALISIS DAN INTERPRETASI DATA}

\subsection{Motivasi Berkesenian Ida Wayan Oka Granoka di Bidang Seni Pertunjukan Bali}

Karya seni tidak terlepas dari adanya faktorfaktor pendorong baik yang bersifat internal (dari dalam diri seniman) maupun yang bersifat eksternal (dari luar dirinya).Dengan demikian seorang seniman mampu menghasilkan sebuah karya-karya seni yang adiluhung. Ada beberapa faktor yang mendorong Granoka untuk menciptakan karya-karya seni pertunjukan, yakni. Pertama, faktor genetik, Granoka adalah keturunan Danghyang Astapaka, dan ayahnya sendiri adalah seorang seniman sejati. Kedua, faktor kompotensi penuh, Granoka adalah seniman yang memiliki kompetensi lengkap meliputi seni sastra,musik, rupa dan tari.Ketiga, faktor sarana dan prasarana, Granoka memilki alat yoga musik yang lengkap dengan MBS. Keempat, faktor dukungan keluarga, semua anggota Granoka keluarga menjadi seniman. Kelima, faktor anugerah, Granoka berkeyakinan bahwa Bhatara sueca 'Tuhan telah memberikan anugerah kepada dirinya'. Keenam, faktor pendidikan, pendidikan keluarga, Granoka dibesarkan dilingkungan keluarga seniman. Berkat didikan Dang guru, Granoka merasa pencapaiannya sekarang adalah berkat didikan Dang gurunya yaitu Prof. Bagus. Menyikapi penomena pendidikan sekarang, kondisi pendidikan manusia saat ini bagi Granoka memerlukan satu entitas pakarana (curriculum vitae).Ketujuh, faktor ekonomi, bekarya yang tidak ada sangkut pautnya dengan kepentingan ekonomi, total ngayah 'tanpa bayaran'. Kedelapan, faktor agama,yoga musik dipersembahkan sebagai yadnya 'pengorbanan'. Kesembilan, faktor idialisme menyangkut tentang niskama karma 'kerja tiada pamrih', pantang menyerah, seni sebagai solusi hidup, idiologi kebangsaan, serta perputaran yadnya cakra 'memutar roda yadnya'. Faktor yang terakhir adalah yang kental yang mendorong Granoka dalam berkreativitas seni.

Kreativitas seniman itu tampak pada kemampuan dalam mengolah tema-tema cerita yang berasal dari teks-teks yang ada, antara lain epos Mahabarata, cerita rakyat, dan 
babad(Kardji, 2007:1--2). Selanjutnya dalam kreativitasnya, seorang seniman berupaya untuk menyadari, mempelajari, dan memupuk kembali realitas yang dialaminya untuk dikreasikan menjadi sebuah pertunjukan. Apapun bentuk karya seni yang dilahirkan, realitas yang dialami oleh seniman kreatornya selalu memberikan pengaruh terhadap karya tersebut. Demikian pula yang dialami oleh setiap manusia menjadi bagian yang tidak dapat dipisahkan dari daya kreatif yang bisa ditumbuhkannya (Ismet, 2007:66).

\subsection{Proses Kreatif Ida Wayan Oka Granoka di Bidang Seni Pertunjukan Bali dan Hasil-hasil Karyanya}

Proses kreatif Granoka dalam seni pertunjukan dimulai dari sebuah proses penciptaan. Penciptaan dalam kata yang sederhana adalah sebuah hasil dari diri individu yang berbeda dan sangat istimewa.Contoh yang paling sederhana adalah sperma dan telur. Getaran yang dihasilkan memiliki kapasitas untuk membawa sebuah bentuk keberadaan dalam setiap titik ruang; artinya bahwa setiap wujud atau bentuk bisa ada dimana saja memberikan kondisi yang dibutuhkan (Ghooi, 2005:36).Untuk menyimak arah pergerakan kreativitas Granoka dalam seni pertunjukan Bali, yang lebih mengarah kepada ritual dari pada pertunjukan, kiranya polaritas efficacyentertainment yang ditawarkan oleh ahli pertunjukan, Richard Schechner, menjadi sangat relevan. Dalam buku Performance Theory (1988), Schechner menawarkan sasaran sebuah pertunjukan ke dalam polar yaitu kemanjuran (efficacy)dan hiburan (entertainment) (1988:120). Dari polaritas ini, kreativitas seni pertunjukan Granoka sarat dengan muatan religius dan spiritual, lebih banyak berada dalam wilayah efficacy 'kemanjuran' untuk mendorong terjadinya pencerahan. Dari sudut pandang ini, Granoka dapat diposisikan atau digolongkan kedalam kreator seni religius yang melahirkan karya-karya sebagai wahana pendakian spiritual (pencerahan).

Proses kreatif Granoka di bidang seni pertunjukan Bali dilakukan melalui beberapa tahapan. Tahap awal yaitu dengan olah raga, olah rasa dan olah yoga dengan melakukan samadhi bhawana 'proses pemurnian pikiran'. Tahap pertengahan yaitu penyederhanaan dari kerumitan fisik serta memahami filofosinya. Tahap akhir yakni pengulangan-pengulangan, menghafalkan, sehingga membentuk penghalusan rasa. Hasil kreativitas Granoka yang utama adalah seni pertunjukan Bali. Hal yang lain sebagai pendukung adalah menyangkut seni sastra daerah Bali, seni lukis, dan seni suara atau vokal. Sedangkan buku-buku karya Granoka di antaranya Memori Bajra Sandhi tahun 1998, Reinkarnasi Budaya tahun 2007, Big Vision Revolusi Moral, Revolusi Yang Tak Terhentikan tahun 2011, dan 70 Tahun Indonesia Merdeka Pesan Kode Genetik 1945-2015 tahun 2016. Dari karya-karya yang dihasilkan Granoka layak mendapatkan beberapa tanda penghargaan, baik yang sifatnya individu maupun secara kelompok. Selain itu Granoka juga mendapat hambatan dan tantangan dalam perjalanan proses kreativitasnya.

\subsection{Pesan-pesan yang Terkandung dalam Kreativitas Ida Wayan Oka Granoka di Bidang Seni Pertunjukan Bali}

\subsubsection{Pesan Kebenaran Religius (Satyam)}

Granoka adalah seorang seniman yang metaksu 'memiliki kekuatan spiritual'. Sebagaimana yang diungkapkan Dibia (2012:1-2), seniman bukanlah orang biasa. Dengan kekuatan taksu 'kekuatan spiritual yang dimiliki para pelaku seni untuk memikat penonton' yang ada pada dirinya, seniman mampu menjadikan sesuatu yang biasa menjadi luar biasa atau mengubah sesuatu yang berharga menjadi sangat berharga. Hanya orang yang dianugerahi kemampuan khusus, bakat, dan keahlian seni, yang mampu melakukan hal seperti itu. Satu hal lagi, setiap seniman memiliki perjalanan karier yang berbeda-beda, termasuk pengalaman jatuh dan bangun, yang sangat bergantung pada kemauan untuk bekerja keras, semangat pantang menyerah, tanpa mengabaikan suratan hidup, dan karma 'buah perbuatan'.

Kreativitas Granoka pertama-tama menonjolkan unsur keseimbangan dua unsur yang saling bertentangan melalui observasi terhadap struktur gamelan yang serba berpasangan, lanang wadon 'laki perempuan', 
dengan kombinasi nada pelog dan juga selendro menjadi satu tidak dipisahkan. Granoka dalam membina anak-anak di sanggar MBS tidak membeda-bedakan dari jenis kelamin, baik lakilaki dan perempuan bisa menyatu dalam satu barungangamelanyoga musik ini, dan selalu menekankan pada rwa bhineda 'dua yang berbeda' ada baik buruk, siang malam, kemudian Siwa Buddha menyatu dalam kebhinekaan.

Kemudian, keativitas Granoka sangat berkaitan dengan pengembangan potensi anakanak yang ikut bergabung dalam kegiatan sanggar MBS. Anak-anak yang dididik gratis, atau tidak ada dipungut bayaran samasekali. Hal ini merupakan nilai-nilai dalam pendidikan kemanusiaan yang perlu dikembangkan ke dalam dunia pendidikan yang lebih luas. Hal yang penting dikembangkan disini adalah menyangkut tentang kesadaran. Darimendengar, melihat penampilan anak-anak dari sanggar MBS menampilkan yoga musik, orang akan merasakan getaran atau vibrasi dari musik yang dimunculkan atau tarian yang disuguhkannya, sehingga terketuk hati mereka dengan kesadaran Mula Prakerti 'kesadaran semesta' yang bersifat primordial.

Jika dicermati kedamaian dalam kreativitas Granoka dalam seni pertunjukan ini adalah mencakup dari tata penggarapan anak-anak yang polos dan lugu, dengan dasar iklas seperti pagelarannya yang sering mengambil cerita dari Sutasoma (seorang yang penuh dengan kesederhanaan dan totalitas keiklasan). Dari hal tersebut kemudian mendatangkan kedamaian, ibaratnya bagaikan air mengalir. Kedamaian berarti ketenangan, keheningan, kejernihan hati, dengan konsep yoga yang dilaksanakan oleh anak-anak dari sanggar MBS implikasinya adalah kedamaian dan keheningan.

Di samping itu, kreativitas Granoka juga menonjolkan pesan pemurnian terhadap diri sendiri Granoka melalui memurnikan makanannyayangdilanjutkandenganpembinaan anak-anak di sanggar MBS ini. Program ini dimulai dari dunia anak-anak yang penuh dengan keluguan, ibarat sebagai kertas putih yang masih murni, baru bangun dari tidurnya tidak ada beban apa-apa dipundaknya. Kemurnian mampu diekspresikan dalam hati yang lembut dan murni saat masih anak-anak, hati yang lugu dan polos ini mewakili purity 'kemurnian hati'. Untuk dapat hidup selaras dan harmonis dalam suatu tatanan masyarakat tentu diperlukan upaya-upaya yang serius didalamnya. Dalam hal ini yang dilakukan oleh Granoka dalam kreativitas seni pertunjukan Bali bersama sanggar MBS adalah yadnya cakra 'memutar roda yadnya melalui sarana yoga musik. Disamping menjalin hubungan yang baik dengan kekuasaan Tuhan dan alam semesta, juga masyarakat sekitarnya menjadi harmonis. Bhagawan Sri Satyha Narayana dalam Sai Uvaca menyebutkan bahwa pemurnian unity, purity, divinity 'kesatuan, kemurnian, ketuhanan'. Itulah tiga prinsip yang harus diingat oleh anakanak. Apa yang dimaksud dengan kesatuan? Aku tidak berbicara tentang prinsip kesatuan dalam kelompok tertentu, atau kesatuan nasional, tetapi juga persatuan di antara bangsa. Aku berbicara tentang kesatuan dalam pikiran, katakata, dan tindakan! Jika manusia memiliki kesatuan dalam pikiran, kata-kata, dan tindakan, hal tersebut mencerminkan kemurnian. Jika kalian memiliki kemurnian, kalian akan mengetahui ketuhanan (Sai, 2015:67).

Kreativitas Granoka dalam seni pertunjukan Bali ini menunjukkan bahwa serangkaian persembahan tidak semata melalui korban suci atau yadnya, tetapi melalui bebantenan atau upakara seperti lazimnya pelaksanaan beragama di Bali. Namun, bagi Granoka persembahan dengan bakti secara tulus melalui yoga musik juga merupakan yadnya. Granoka memutar roda yadnya melalui seni, sedangkan para pendeta memutar yadnya melalui puja-puja mantra dan sarana upacara. Hal tersebut tidak bertentangan sepanjang tidak merugikan masyarakat. Dengan jalan bagaimanapun umat mendekati Tuhan, dengan cara seperti itulah Beliau memberikan anugerahnya, seperti yang tersirat dalam kitab Bhagawadgita (IV. 11) sebagai berikut.

Ye yathā mam prapadyante tāms tathai 'vabhajāmy aham mama vartmā 'nuvartante manușyāḥārtha savaśạ

Artinya:

Dengan jalan bagaimanapun orang-orang mendekati dengan jalan yang sama itu 
juga Aku memenuhi keinginan mereka. Melalui banyak jalan manusia mengikuti jalan-Ku, O Partha.

Berdasarkan sloka yang tersirat dalam kitab Bhagawadgita tersebut jelas bahwa aktivitas yadnyaapa pun bisa dilakukan, termasuk melalui jalan seni. Di Bali banyak seniman yang merasa cukup hanya dapatngayah megambel'memainkan gamelan' atau menari, tidak perlu lagi untuk cakupang lima, mebakti 'sembahyang', itulah rasa bakti kepada Tuhan melalui jalan seni.

Dari perputaran yadnya tersebut, dapat dilihat betapa anak-anak MBS dengan penuh dedikasi, tiada pernah menyerah dalam situasi apa pun, memutar roda yadnya, baik hujan panas, tengah malam, atau pagi-pagi betul untuk meyadnya 'berkorban melalui seni yoga musik ini. Walaupun dengan biaya sendiri, mereka tetap tidak bergeming tampil di beberapa tempat yang dipandang strategis untuk melaksanakan yadnya ini. Inilah sebuah sebuah yadnya 'pengorbanan' yang selalu ditanamkan di MBS oleh Granoka. Berkat didikan disiplin Granoka, anak-anak memahami arti sebuah yadnya yang sesungguhnya.

\subsubsection{Pesan Kesucian Religius (Siwam)}

Dalam kaitannya dengan kreativitas Granoka dalam seni pertunjukan Bali adalah menyangkut ajaran Siwa Buddha di Nusantara yang memiliki berbagai ragam kebudayaannya yang sangat popular di manca negara, dengan berbagai adat dan budaya yang berbeda-beda, syukurlah di negara ini terdapat suatu paham Bhineka Tunggal Ika'berbeda-beda namun tetap satu jua'. Phalgunadi, (2010) menyatakan kebhinekaan adalah sebuah keniscayaan. Dalam kebhinekaan terdapat keesaan nilai yang ajeg sepanjang masa. Ajaran Siwa yang ada di Bali adalah adalah ajaran Çiwa Sidhanta yang telah melebur dalam konsep Tri Murti. Brahma sebagai pencipta berstana di pura Desa atau Bale Agung, Wisnu sebagai pemelihara berstana di pura Puseh, dan Siwa sebagai pelebur mengembalikan ke asalnya berstana di pura Dalem. Konsep Tri Murthi ini mengejewantah di desa Pakraman yang keberadaannya hampir di seluruh desa-desa yang ada di Bali.

Salah satu bentuk madzab yang timbul dalam madzab Mahayana dan merupakan ajaran agama Buddha, ialah madzab Tantrayana yang juga dikenal dengan madzab Mantrayana. Perkembangan dari madzab ini merupakan akibat langsung yang timbul dari pengaruh madzab Ciwaisme dari agama Hindu (Tim Penyusun, 2012: 5). Kebenaran sempurna tidak diperuntukkan bagi orang biasa. Mereka harus menyadari dan pengetahuan lengkap ini tidak bisa didapatkan tanpa yoga yang sangat penting dalam ajaran Buddha (Gombrich, Theravada Buddhism dalam Armstrong, 2005: 168).

Proses penyatuan agama Hindu dan Buddha, yang sudah dimulai di Jawa Tengah, serta dikembangkan pada zaman Empu Sindok, Kediri, dan Singasari, mencapai puncaknya pada zaman Majapahit. Tidak ada lagi perbedaan antara Siwa dan segala penjelmaannya dengan Buddha dan segala penjelamaannya (Hadiwijono, 2010: 131). Kemudian berikutnya setelah runtuhnya kerajaan Majapahit, ajaran Siwa dan Buddha berkembang pesat di Bali. Phalgunadi (2010) menyatakan tidak pernah ada penyatuan agama Siwa dan Buddha seperti yang terjadi di Bali di seluruh belahan dunia manapun. Inilah format baru yang ada, bahwa Bali mampu memberikan ruang yang dapat meyatukan dua pandangan agama yang hidup sejajar dari zaman dulu yang di India sendiri dimana agama Hindu dan Buddha dilahirkan tidak bisa menyatukan kedua agama tersebut, bahkan saling bermusuhan. Proses kreatif Granoka dalam berkreativitas dalam seni pertunjukan Bali ini, masih mengadopsi ajaranajaran yang memegang teguh kepada kitab Sutasoma dan Sanghyang Kamahayanikan. Ajaran-ajaran inilah yang diolah oleh Granoka sebagai bentuk kreativitasnya untuk melahirkan seni pertunjukan Bali yakni yoga musik $P G$.

Buddha Keling (Budakeling) bukanlah suatu ajaran namun adalah nama tempat yang terletak di daerah kaki Gunung Agung tepatnya di Kecamatan Bebandem, Kabupaten Karangasem. Dengan demikian Budakeling dapat diartikan dengan suatu tempat kehadiran seorang pandita yang menganut paham Buddha Mahayana yang berasal dari daerah Keling Jawa Timur.

Musik atau gamelan di Bali dilambangkan dengan hulu atau suara. Posisi hulu yang lain mengikuti, seperti seekor kelinci, di mana 
kepalanya, ekornya pasti mengikuti. Inilah esensi bunkti I (ding) di hulu adalah tertinggi, linguistik bunyi I sebagai bunyi yang tertinggi I ring 'di'nding, gending 'tembang' ring nding gending menentukan nding. Pergerakan manusia sesungguhnya dari sarira prasada menuju dewa prasada. Ongkara merupakan musik batin. Bijaksara menjadi inti padma cakra berputar yang memutar cakra sendiri, melambangkan perputaran (wawancara, dengan Granoka 12 Mei 2016).

\subsubsection{Pesan Estetika Religius (Sundaram)}

Salah satu aspek tantraadalah pandangan mengenai dunia spiritual. Dalam hal ini salah satu alasan utama manusia menderita adalah karena pandangan manusia terhadap dunia yang materialistik dan dualistik. Manusia melihat dan mengalami kehidupan sebagai seriseri yang saling terpisah antara satu even dan even yang lain, yang memberikan penderitaan ataupun kesenangan. Dengan membudidaya pandangan hidup spiritual, orang dapat belajar melihat dan mengalami dunia sebagai sebuah peristiwa yang terus berlanjut. Akhirnya melihat sebagai satu kesatuan yang utuh, sebagai Brahma. Manusia bisa belajar untuk melampaui kesenangan dan penderitaan dan menemukan sesungguhnya yang diinginkannya, yaitu kedamaian di dalam (Bjonness, 2015:13).

Ida Pedanda Putra Telabah menyatakan bahwa konsep yoga yang dilaksanakan oleh anak-anak sanggar MBS telah dilaksanakan secara sempurna dengan menghadirkan presentasi kolosal. Implikasinya adalah kedamaian, keheningan, atau bisa disebutkan sebagai praktik agama yang sejati. Yoga musik, yaitu bebarungangamelan 'kesatuan dalam instrumentalnya' sangat besar yang disebut dengan maha. Instrumentalnyaitu menimbulkan suara gemuruh, tetapi berkesenian yang hiper 'berlebihan'. Semua itu dirangkum secara keseluruhan sehingga menimbulkan keharmonisan. Keharmonisan tersebut dipadukan dalam konsep yogasastra,yoga tantra, yoga nada, dan yoga kalpa di bawah asuhan Pendeta Siwa, Pendeta Buddha, dan Pendeta Siwa Buddha (Semadi, 2012:143--144).

Seni pertunjukan karya Granoka yang dituangkan dalam seni tabuh atau gamelan Bali, yangmengambil inspirasidarigamelanselonding. Gamelan ini dirasakan memberikan suasana yang penuh dengan kedamaian. Ketika mendengar tabuh-tabuh selonding sepertinya tidak sedang berada di dunia ini. Tusan (2002:190) menyatakan bahwa gamelan selonding lahir sebagai suatu penuangan ide dan konsep-konsep yang cemerlang. Ide dan konsep itu berasal dari para leluhur yang diciptakan dalam suasana jiwa yang sedang menikmati rasa kedamaian dan kesucian yang tinggi (ekstasis). Hal itu dipersembahkan sebagai sarana kebaktian (yantra) kehadapan Sang Pencipta dan pengabdian kepada masyarakat.

Setiap seniman selalu berusaha mengadakan penyatuan dalam sebuah garapan seni sehingga mampu mencapai puncak tertinggi dari garapannya. Disini dapat dikatakan bahwa setiap perjuangan seorang seniman dalam penggarapannya ingin atau rindu terhadap sang pemilik seni yang sejati, yaitu Tuhan. Pada tingkatan atau dalam tingkatan proses pendakian berkesenian seniman disamakan dengan perjuangan seorangyogi yang juga rindu untuk bersatu dengan Tuhan(Yudabakti, 2007:13).Sosok seniman seperti Granoka dalam berkesenian memandang dan meyakini bahwa berkesenian merupakan suatu proses untuk mempersatukan kembali sang pelaku seni itu ke hadapan Sang Maha Pencipta.

Estetika dalamrasayang dilakukan Granoka dalam kreativitasnya adalah mengolah bhatin sehingga mampu menghasilkan karya-karya dalam yoga musik ini. Atinta rasa 'rasa berada dipuncak hati', dengan pengolahan rasa ini, yang bersentuhan dengan jiwa, maka disadari atau tidak jiwa bertemu dengan jiwa itu sendiri, maka terjadilah penyatuan. Tujuan hidup sebagaimana digariskan dalam ajaran agama Hindu adalah menunggal atau menyatu dengan Ida Sanghyang Widhi Wasa, Tuhan Yang Maha Kuasa yang disebut Moksa 'kebebasan'.

Granoka melakukan aktivitasnya dalam berkesenian dengan menekuniyogamusik sebagai realisasi pencarian diri, menemukan hakekat diri sejati melalui musik. Dengan demikian kegiatan yang dilakukan melalui proses mengolah bhatin melalui jalan yoga menuju pada pencerahan. Bagi seorang seniman yang sedang berkarya untuk menuangkan 
imajinasinya ke dalam sebuah bentuk garapan karya seni yang adiluhung, maka bagi Granoka jalan yoga yang ditempuhnya dengan aktivitas yoga musiknya, menjadikan jalan ini sebagai sebuah persembahan semata. Menabuh atau memainkan alat musik bagi Granoka adalah sebuah obsesi dalam proses melakukan tahapan-tahapanyoga.

Dalam praktiknya, di sanggar MBS,Granoka mengarahkan anak-anak untuk berperilaku baik, jujur dalam beberapa hal, seperti: yama 'pengendalian diri': tidak menyakiti,jujur,tidak mencuri, mengekang nafsu seks, dan dengan hidup sederhana. Berikutnyaniyama 'pembinaan sifat-sifat baik' dengan cara menyucikan diri lahir bhatin, menjaga kesentosaan hati, tahan uji, hidup mandiri, dan bhakti kepada Tuhan; diwujudkan dengan selalu bersifat ngayah 'persembahan dengan tulus iklas pada Tuhan tidak ada imbalannya'. Kemudian anak-anak diarahkan untuk sikapāsana 'olahraga pisik dapat duduk sempurna'. Kemudian prānāyāma 'olah nafas agar nafas vital terkendali', dilakukan dengan pengaturan nafas sebelum mulai mengambil nada-nada. Berikutnya prathyāhāra 'mengarahkan pikiran (indra) ke dalam diri', dengan mengarahkan pusat perhatian pikiran ke nada-nada yang dimainkan, baik nada yang sedang berjalan maupun nada yang dimainkan. Dilanjutkan dengan dhāranā 'menyatukukuhkan dan mengkonsentrasikan pikiran (indra) pada objek meditasi'. Dhyāna 'mengalirkan pikiran secara konstan ke objek konsentrasi; kontemplasi', dan hasilnya adalahsamādhi'diam dalam kemanunggalan'.Hal ini sejalan dengan teori yoga dalam yoga sutra Patanjali. Hal yang terakhir yang dibicarakan dalam yogaadalah tahap pencapaian kesempurnaan dengan Tuhan yakni lebur dalam diam. Samādhi artinya telah menyatu dengan Tuhan.

Estetika yogamusik, menurut Granoka, membedah perspektif yoga, yang konsepnya dari Yogasutra Pantanjali. Hal ini merupakan sebuah pergeseran epestemik yang belum mampu dijamah oleh pertunjukan. Kreativitas itu masih bebas, belum diturunkan ketaraf pemikiran. Yoga musik yang dirancangnya esensinya bukanlah mengacu kepada seni pertunjukan sebagaimana biasa.Jika dikatakan seni pertunjukan, hal tersebut membingkai seni itu sendiri, justru tidak akanmampu berkembang. Pertunjukan mengekang ideaslisme, belum mampu diturunkan menjadi taksonomi. Yoga musik itulah hasil kreatif sekalian bukan untuk Bali saja, tetapi sebuah estetika menuju pada pembebasan.

Pada dasarnya segala aktivitas berkesenian Granoka adalah Samadhi Bhawanadalam bentuk samadhi gending yang diformulasikan dari gending-gending atau tabuh dalam yoga musik. Melalui sarana yoga musik ini diharapkan para peserta pelatihan bisa masuk ke tataran samadhi. Samadhi adalah puncak dalam pencapaian semuanya ini. Inilah sebuah pendakian yang mengarah kepada hal-hal yang bersifat spiritual. Cepat atau lambat dengan sebuah keyakinan yang mendasar, hal ini pasti akan terwujud, karena digariskan memang tujuan manusia untuk kembali kepada Tuhan Yang Maha Kuasa yang agama Hindu disebut moksa 'kebebasan'.

\section{SIMPULAN}

Proses kreatif Granoka adalah olah rasa melalui proses yoga. Artinya, apa yang dilakukan Granoka sesungguhnya mengaplikasikan teori kreativitas, teori rasa, dan teori yoga secara terpadu. Dalam konteks rasa, Granoka memulai proses kreatifnya dari adbutha rasa 'rasa takjub' menuju sānta rasa 'rasa damai'. Dalam proses pembangkitan rasa itulah Granoka melakukan yoga dengan puncaknya samadhi bhawana 'membangun pikiran murni'Bagi Granoka bermain musik dan menari adalah sebuah yoga. Motonya Magambel Ida mayoga, masolah Ida mayoga 'menabuh Beliau melakukan yoga, menari juga Beliau melakukan yoga'.Dengan berkesenian Granoka mengembangkan konsep pendakian spiritual dalam tiga kerangka pemikiran yang terpadu, yakni musik, linguistik, dan mistik 'kesenian, bahasa, kemanunggalan'. Dalam konteks spiritual, Granoka membatinkan dan mengekspresikan satyam atau tattwa, siwam atau susila dan sundaramatau ritual sebagai inti pesan dalam karya seninya.

Tujuan Granoka berkesenian adalah untuk mengukuhkan dan menyosialisasikan Bhineka Tunggal Ika dan Pancasila Krama dalam konteks kebangsaan.Bagi Granoka berkesenian secara 
total penuh rasa bakti adalah ber-yadnya. Granoka meyakini bahwa hidup dengan pola makan vegetarian dapat menumbuhkan kecintaan terhadap sesama serta menumbuhkan kepekaan estetik dan religius. Dengan disiplin dan penuh kasih, Granoka berhasil menjadikan keluarganya sebagai seniman-seniman total.
Praktik berkesenian Granoka mengabdikan diri secara total, yaitu mengintegrasikan berbagai unsur seni, seperti tari, musik, drama, dan sastra.Granoka dapat disebut sebagai seorang seniman agung yang religius, yang bercita-cita merevitalisasi nilai agama budaya dan adat Hindu Bali dalam menghadapi arus global.

\section{DAFTAR PUSTAKA}

Armstrong, Karen. 2005. Buddha. Yogyakarta: BENTANG (PT Bentang Pustaka).

Bungin, Burhan. 2012. Analisis Data Penelitian Kualitatif. Jakarta: PT RajaGrafindo Persada.

Dibia, I Wayan. 2003. "Nilai-Nilai Estetika Hindu dalam Kesenian Bali" dalam Estetika Hindu dan Pembangunan Bali. Denpasar: Program Magister Ilmu Agama dan Kebudayaan Universitas Hindu Indonesia Bekerjasama dengan Penerbit Widya Dharma.

Dibia, I Wayan. 2012. Mongkah Tanah Lawang Biografi Seniman I Wayan Geria. Yogyakarta:Kanisius. Ghooi, Charanjit. 2005. Bakti dan Kesehatan. Surabaya: Paramita.

Granoka,Ida WayanOka. 2010."Prabhaswara Timur Raya Makalah dibawakan pada seminar "Dunia Baru, Fajar Kebangkitan Bangsa”. DPC GMNI Denpasar.

Hadiwijono, Harun. 2010. Agama Hindu dan Buddha. Jakarta: PT BPK Gunung Mulia.

Hermansyah. 2007. Mamanda Sebuah Teater Eksodus. Yogyakarta: Balai Kajian dan Pengembangan budaya Melayu.

Ismet, Adang. 2007. Seni Peran.Bandung:Kelir.

Jatman, Darmanto. 1985. Sastra, Psikologi, dan Masyarakat. Bandung: Alumni.

Kardji, I Wayan. 2007. Topeng Prembon dan Mantra Sang Penari. Denpasar: PANAKOM Publishing.

Phalgunadi, I Gusti Putu. 2010.Sekilas Sejarah Evolusi Agama Hindu. Denpasar: Program Magister Ilmu Agama dan Kebudayaan Universitas Hindu Indonesia Bekerja sama dengan Widya Dharma.

Sai, Sri Sathya Uvacha. Volume One. 2015. Divine Discourses of Bhagawan Sri Sathya Sai Baba in Subtle Body. Karnataka, India: Sri Sathya Sai Premamruta Prakashana (R), A-24, Saidham, Sathya Sai Grama, Muddenahalli, Chikballapur Taluk and District-562101.

Semadi, Gusti Ngurah Yoga. 2012. "Perburuan ke Prana Jiwa Yoga Musik Pakarana Gamelan di Sanggar Maha Bajra Sandhi Banjar Batu Kandik, Denpasar". Tesis (tidak diterbitkan) Program Pascasarjana Universitas Hindu Indonesia Denpasar.

Schechner, Richard. 1988. Performance Theory. (Revised and Expended edition). New York: Routledge.

Soedarsono. 2011. Seni Pertunjukan dari Perspektif Politik, Sosial, dan Ekonomi.Yogyakarta:Gadjah Mada University Press.

Suryana. 2013. Ekonomi Kreatif Ekonomi Baru: Mengubah Ide dan Menciptakan Peluang. Jakarta: Salemba Empat.

Sumaryono. 2007. Seni Pertunjukan Kita.Yogyakarta:Prasista.

Tim Penyusun. 2012. Sanghyang Kamayanikan. Denpasar: ESBE Buku.

Tusan, Pande Wayan. 2002. Selonding Tinjauan Gamelan Bali Kuna Abad X-XIV (Suatu Kajian Berdasarkan Data Prasasti, Karya Sastra dan Artefak).Karangasem: Citra Lekha Sanggraha.

Yudabakti, I Made \& Watra, I Wayan. 2007. Filsafat Seni Sakral dalam Kebudayaan Bali. Surabaya: Paramita. 